\title{
Isotherm Models of Heavy Metal Sorption onto Zinc-tricarboxylic
}

\author{
C. Kowsura, B. Pangkumhang, P. Jutaporn, and V. Tanboonchuy
}

\begin{abstract}
Zinc-tricarboxylic (Zn-BTC) consists of Zinc Acetate Dihydrate $\left(\mathrm{Zn}\left(\mathrm{CH}_{3} \mathrm{COO}\right)_{2} \cdot 2 \mathrm{H}_{2} \mathrm{O}\right)$ and $1,3,5$ Benzenetricarboxylic Acid $\left(\mathrm{H}_{3} \mathrm{BTC}\right)$, a well-known metal-organic framework (MOFs). It was synthesized by hydrothermal process. This study was established to analyze the capability of $\mathrm{Pb}(\mathrm{II})$ and $\mathrm{Cu}(\mathrm{II})$ adsorption onto $\mathrm{Zn}-\mathrm{BTC}$ synthesized. The adsorption isotherms of $\mathrm{Pb}(\mathrm{II})$ and $\mathrm{Cu}$ (II) were compared to Langmuir, Freundlich, and Dubinin-Radushkevitch models. The results show greater correlation coefficient between these two adsorption isotherms and Langmuir model. The maximum adsorption capacities of the synthesized $\mathrm{Zn}$-BTC were $416.7 \mathrm{mg} / \mathrm{g}$ for $\mathrm{Pb}(\mathrm{II})$ and $85.5 \mathrm{mg} / \mathrm{g}$ for $\mathrm{Cu}$.
\end{abstract}

Index Terms - Zinc-tricarboxylic, MOFs, sorption, heavy metal, $\mathrm{Pb}(\mathrm{II}), \mathrm{Cu}(\mathrm{II})$.

\section{INTRODUCTION}

Heavy metals contamination in water is one of the major environmental concerns. Heavy metals from heavy industry, agricultural, and other human activities could enter the water body and cause danger to the environment and human health. Heavy metals, such and lead $(\mathrm{Pb})$ and copper $(\mathrm{Cu})$, are commonly found in the discharged wastewater form industries. Industrial sector has to comply with environmental regulations to treat their wastewater. For example, Pollution Control Department of Thailand regulated maximum allowable concentrations of $\mathrm{Pb}$ and $\mathrm{Cu}$ in treated effluent to be $0.2 \mathrm{mg} / \mathrm{L}$ and $2 \mathrm{mg} / \mathrm{L}$, respectively [1] Heavy metal, even in low concentration, can bioaccumulate in a biological organism over time. This treated effluent, even though meets standard in term of concentration, but the presence of trace heavy metals in large volume of discharged effluent can still cause environmental impact in industrialized area.

Toxicity of heavy metal includes obstructive lung disease, reduced growth and development, cancer, organ damage, nervous system damage, and in extreme cases, death. Heavy metals, such as arsenic, cadmium, copper, lead, mercury, nickel, are regulated in drinking water by The World Health Organization (WHO) [2]. Electronic industry is one of the major parties in heavy metals discharge in wastewater stream.

Manuscript received January 11, 2017; revised May 3, 2017. This work was supported by Department of Environmental Engineering, Faculty of Engineering, Khon Kaen University, Khon Kaen, 40002, Thailand and Research Center for Environmental and Hazardous Substance Management (EHSM), Khon Kaen University, Khon Kaen, 40002, Thailand.

C. Koesura, B. Pangkumhang, P. Jutaporn, and V. Tanboonchuy are with Department of Environmental Engineering, Faculty of Engineering, Khon Kaen University, 40002, Thailand (e-mail: nay_chanut@kkumail.com, bhuckchanya@gmail.com, panitju@kku.ac.th, and visanu@kku.ac.th).
This study focuses on $\mathrm{Pb}$ and $\mathrm{Cu}$ because they can be found in abundance in wastewater from electronic industry.

Lead is considered a carcinogenic substance. It has adverse effect on human organs and can also cause disability in newborns. Copper is an essential trace element for living organism but excessive $\mathrm{Cu}$ acute exposure can cause vomiting and hypotension. Chronic effects of $\mathrm{Cu}$ exposure can damage the liver and kidneys and also Wilson's Diseases syndrome [2].

The current technologies used for heavy metals removal are precipitation, ion exchange, and adsorption process [1]-[4]. Removal by adsorption process is our major focus because the process was simple and effective [5]. Absorbents used in previous studies for heavy metal removal by adsorption process were activated carbon [4] and Zeolite [7]-[9]. A new type of absorbent material that has potential to be used for heavy metals adsorption is metal-organic frameworks.

Metal-organic frameworks (MOFs) consist of network framework of metal ions and organic molecules binding together with covalent bond, resulting in multiple dimensions structure [10]. MOFs are the highly crystalized and adjustable in porosity. The main advantage of MOFs is that their pore size and porosity can be designed to adsorb specific contaminants [11] and their structure can also be customized for the chemical specificity[12]. MOFs can be synthesized by variety of methods, such as microwave [13] and ultrasonic [14]. The commonly employed synthesis method is hydrothermal/solvothermal, which is a synthesis using heat [15]. Potential applications of MOFs adsorbents include gas storage and separation [12], ion exchange and chemical sensing [16]. It can also be used to control release of copper ions for antifungal propose [17]. Over all, application MOFs is a promising technology to be applied in full industrial scale. With these advantages of MOFs, they are attractive for new research. Previous study [18] reported that using MOF-808 as adsorbent is efficient at arsenic removal from water. $\mathrm{Cu}_{3}$ (BTC) $)_{2}-\mathrm{SO}_{3} \mathrm{H}$ also exhibited high $\mathrm{Cd}(\mathrm{II})$ uptake capacity, thus has a potential use for cadmium removal [19]. Other type of MOFs previously used in heavy metals absorption studies were Graphene Oxides (GO) [4], [6], EDTA-Graphene Oxide (EDTA-GO) [3], [20] for Pb(II) removal and MOF-5 [16] and Graphene Oxides-CdS [21] for $\mathrm{Cu}$ (II) removal. However, an optimum experimental conditions to maximize heavy metals absorption efficiency of MOFs were not well studied.

This study uses adsorption isotherm to evaluate the used of $\mathrm{Zn}-\mathrm{BTC}$ as an adsorbent to remove $\mathrm{Pb}$ (II) and $\mathrm{Cu}$ (II). The $\mathrm{Zn}$-BTC used in this study included Zinc Acetate Dihydrate $\left(\mathrm{Zn}\left(\mathrm{CH}_{3} \mathrm{COO}\right)_{2} \cdot 2 \mathrm{H}_{2} \mathrm{O}\right)$ and 1,3,5 Benzenetricarboxylic Acid (H3BTC), which was synthesized by hydrothermal process The adsorption isotherms of $\mathrm{Pb}$ (II) and $\mathrm{Cu}(\mathrm{II})$ by $\mathrm{Zn}-\mathrm{BTC}$ 
were compared to Langmuir, Freundlich, and Dubinin-Radushkevitch models and optimum experimental conditions were also determined.

\section{MATERIALS AND METHODS}

\section{A. Chemical and Reagents}

Zinc Acetate Dihydrate $\left(\mathrm{Zn}\left(\mathrm{CH}_{3} \mathrm{COO}\right)_{2} \cdot 2 \mathrm{H}_{2} \mathrm{O}\right)$, Benzenetricaboxylic acid $\left(\mathrm{H}_{3} \mathrm{BTC}\right)$, were obtained from Sigma-Aldrich, Saint Louis, USA and Ethanol were obtained from RCL Labscan Ltd., Bangkok, Thailand. The 1000 $\mathrm{mg} / \mathrm{L}-\mathrm{Pb}$ (II) and $1000 \mathrm{mg} / \mathrm{L}-\mathrm{Cu}$ (II) stock solutions were prepared from dissolving $\mathrm{Pb}\left(\mathrm{NO}_{3}\right)_{2}$ and $\mathrm{CuSO}_{4} \cdot 5 \mathrm{H}_{2} \mathrm{O}$ in deionized water, respectively. $\mathrm{HNO}_{3}$ and $\mathrm{NaOH}$ were used to adjust the $\mathrm{pH}$ of the stock solutions as required.

\section{B. Zn-BTC Synthesis}

Zn-BTC was synthesized by hydrothermal method using $\mathrm{ZnAc} \cdot 2 \mathrm{H}_{2} \mathrm{O} 0.99 \mathrm{~g}$ dissolved in $75 \mathrm{~mL}$ deionized water, then the solution was stirred for 30 minute. $0.64 \mathrm{~g}$ of $\mathrm{H}_{3} \mathrm{BTC}$ was also dissolved in $75 \mathrm{~mL}$ ethanol and stirred for 30 minute. The $\mathrm{ZnAc} \cdot 2 \mathrm{H}_{2} \mathrm{O}$ and $\mathrm{H}_{3} \mathrm{BTC}$ solutions were mixed together then stirred for another 30 minute. The mixture was then poured into Teflon-line stainless steel autoclave and heated to $103-105{ }^{\circ} \mathrm{C}$ for 24 hour. The Zn-BTC solution was dried at $200{ }^{\circ} \mathrm{C}$ in a electric muffle furnace for 24 hour and then the furnace temperature was increased to $350{ }^{\circ} \mathrm{C}$ for another 2 hour. This $\mathrm{Zn}-\mathrm{BTC}$ was used as an adsorbent to remove $\mathrm{Pb}$ (II) and $\mathrm{Cu}$ (II) from aqueous solution. The $\mathrm{Zn}-\mathrm{BTC}$ was characterized by X-ray diffraction analysis )XRD) (Model D8 Discover, Bruker AXS Germany) and point of zero charge $\left(\mathrm{pH}_{\mathrm{pzc}}\right)$.

\section{Batch Adsorption Experiment}

Batch adsorption experiments were performed to determine the time of mixing needed to reach equilibrium of $\mathrm{Pb}$ (II) and $\mathrm{Cu}$ (II) adsorption by Zn-BTC. $20 \mathrm{mg} / \mathrm{L} \mathrm{Pb}$ (II) and $20 \mathrm{mg} / \mathrm{L} \mathrm{Cu}$ (II) working solutions were prepared from the $1000 \mathrm{mg} / \mathrm{L}$ stock solutions. $\mathrm{HNO}_{3}$ and $\mathrm{NaOH}$ were used to adjust $\mathrm{pH}$ of $\mathrm{Pb}$ (II) and $\mathrm{Cu}$ (II) working solutions to $6 \pm 0.5$ and $5 \pm 0.5$, respectively $[3,22]$. In the batch experiments, 0.5 $\mathrm{g}$ of $\mathrm{Zn}-\mathrm{BTC}$ was added to $\mathrm{Pb}$ (II) and the $\mathrm{Cu}$ (II) working solutions separately. The water samples were collected over the time span of $0-120$ minute. Treated water samples were analyzed by Atomic Absorption Spectroscopy (AAS) (Perkin-Elmer AAnalyst 800).

The adsorption capacities were calculated by the following equation [23]:

$$
\% \text { Removal }=\frac{C_{0}-C}{C_{0}} \times 100
$$

where $C_{0}$ and $C$ are the initial concentration of heavy metal $(\mathrm{mg} / \mathrm{L})$, and the final concentration of heavy metal $(\mathrm{mg} / \mathrm{L})$, respectively.

\section{Isotherm Models for the Adsorption of Heavy Metals}

In isotherm models study, different initial concentrations of $\mathrm{Pb}$ (II) and $\mathrm{Cu}$ (II) were varied from 5-300 $\mathrm{mg} / \mathrm{L}$ and the $\mathrm{pH}$ of each solutions was kept constant at $6 \pm 0.5$ and $5 \pm 0.5$, respectively. $0.025 \mathrm{~g}$ of $\mathrm{Zn}-\mathrm{BTC}$ was added to $50 \mathrm{~mL}$ of heavy metal solutions and 60 min-mixing was provide by was a rotating mixer. Adsorption kinetics were compared to
Pseudo-first and second orders [23], [24].

Pseudo-first order is described by the equation:

$$
\frac{d q_{t}}{d t}=k_{1}\left(q_{e}-q_{t}\right)
$$

Pseudo-second order is described by the equation:

$$
\frac{d q_{t}}{d t}=k_{2}\left(q_{e}-q_{t}\right)^{2}
$$

where $q_{e}(\mathrm{mg} / \mathrm{g})$ and $q_{t}(\mathrm{mg} / \mathrm{g})$ are the amount of heavy metals uptake on the adsorbent at the equilibrium and at time $t$, respectively. $k_{1}$ and $k_{2}$ are the rate constant of pseudo-first and second orders, respectively.

Results of adsorption isotherms from the experiments were compared to Langmuir, Freundlich, and Dubinin-Radushkevitch isotherms [22]-[24] and isotherm models fitting was evaluated using $R^{2}$ values.

Langmuir isotherm assumes that adsorption process is a monolayer adsorption of adsorbate onto a homogeneous surface of adsorbent. Langmuir isotherm can be described by the following equation [24], [25]:

$$
q_{e}=\frac{q_{\max } K_{L} C_{e}}{1+K_{L} C_{e}}
$$

where $q_{e}$ and $q_{\text {max }}$ are the amount of heavy metals uptake on the adsorbent at the equilibrium $(\mathrm{mg} / \mathrm{g})$ and at maximum adsorption capacity $(\mathrm{mg} / \mathrm{g})$, respectively. $K_{L}$ is the rate constant of Langmuir isotherm, and $C_{e}$ is the concentration of adsorbate at the equilibrium $(\mathrm{mg} / \mathrm{L})$. The equation can be rearranged find the values of $q_{\max }$ and $K_{L}$ by linear regression method with graphical approach. Experimental data $\frac{1}{q_{e}}$ can be plotted as a function of $\frac{1}{C_{e}}$ as described by the equation:

$$
\frac{1}{q_{e}}=\frac{1}{q_{\max } K_{L} C_{e}}+\frac{1}{q_{\max }}
$$

Freundlich isotherm was based on assumptions of multilayer adsorption of adsorbate onto heterogeneous surface of adsorbent with non-uniform distribution of heat of adsorption. Freundlich isotherm is described by the following equation [24], [25]:

$$
q_{e}=K_{F} C_{e}^{1 / n}
$$

where $K_{F}$ is the rate constant of Freundlich isotherm and $\mathrm{n}$ is the adsorption intensity.

Equation (6) can be rearranged in the form of linear equation to find the value $n$ and $K_{F}$ using graphical method. In $q_{e}$ is can be plotted as a function of $C_{e}$ by the equation:

$$
\ln q_{e}=\ln K_{F}+\frac{1}{n} C_{e}
$$

Dubinin-Radushkevitch isotherm describes the mechanism of adsorption of a physical adsorption or chemical adsorption. Dubinin-Radushkevitch isotherm is described by the equation [24].

$$
q_{e}=q_{\max } e^{-\delta \varepsilon^{2}}
$$

Equation (8) can be rearrange as:

$$
\ln q_{e}=-\delta \varepsilon^{2}+\ln q_{\max }
$$

where $\delta$ is the rate constant of the energy absorption per quantity of adsorbent $\left(\mathrm{mol}^{2} / \mathrm{J}^{2}\right)$, and $\varepsilon$ is the Polanyi potential. $\varepsilon$ is determined by the following equation 


$$
\varepsilon=R T \ln \left(1+\frac{1}{C_{e}}\right)
$$

where $R$ is the gas constant $(\mathrm{J} / \mathrm{mol}-\mathrm{K})$, and $T$ is temperature $(K)$.

The free energy $(E, \mathrm{~kJ} / \mathrm{mol})$ of sorption per molecule of adsorbent occur when adsorbate moves to the surface of the solid in solution, and can be describe by the equation:

$$
E=\frac{1}{\sqrt{2 \delta}}
$$

$E$ can be used to categorize adsorption process. If the value of $E$ is between $8-16 \mathrm{~kJ} / \mathrm{mol}$, the process is considered chemical absorption, while the value of $E<8 \mathrm{~kJ} / \mathrm{mol}$ indicates physical absorption nature.

\section{RESULTS AND DISCUSSION}

\section{A. Characterization of the Adsorbent}

The Zn-BTC was characterized by X-ray diffraction analysis (XRD) (Model D8 Discover, Bruker AXS Germany). The XRD pattern was collected using continuous scan mode in $2 \theta$ range between $5-50^{\circ}$ with a scanned speed at a counting time of $1 \mathrm{~s}$ per step. The instrument was operated at $40 \mathrm{kV}$ and $40 \mathrm{~mA}$ using as a source copper radiation [13], [15]. The phase structure of Zn-BTC sample by XRD pattern was shown in Fig. 1. The flat shape of XRD pattern after the main peak suggests that Zn-BTC has a crystallized structure with high purity.

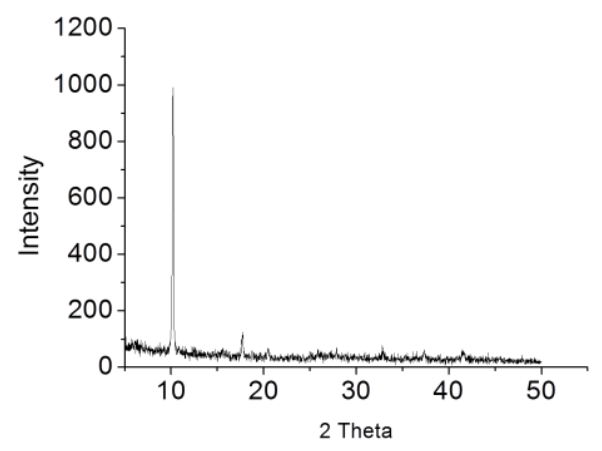

Fig. 1. Characterization pattern of the synthesized Zn-BTC by X-Ray Diffraction Analysis (XRD).

Fig. 2 illustrates the point of zero charge $\left(\mathrm{pH}_{\mathrm{pzc}}\right)$ for Zn-BTC. $0.1 \mathrm{~g} \mathrm{Zn-BTC}$ was added into $1 \mathrm{M} \mathrm{NaCl}$ solution and the $\mathrm{pH}$ adjustment from 2 to 11 was done by addition of $\mathrm{HCl}$ and $\mathrm{NaOH}$. Then the aqueous solution was shaken for 48 hour.

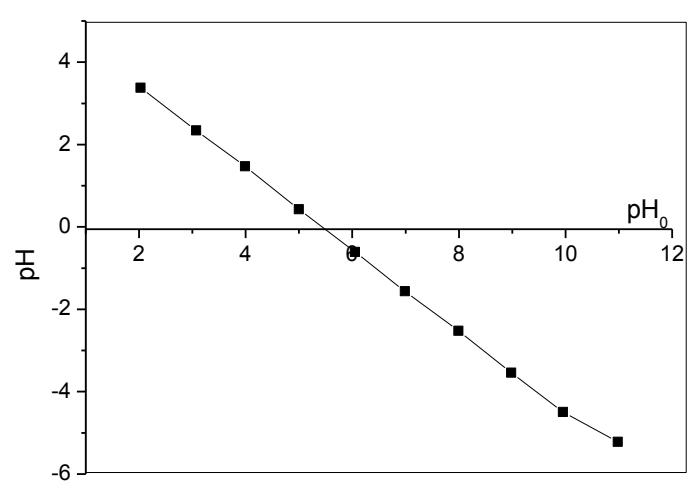

Fig. 2. Point of Zero Charge $\left(\mathrm{pH}_{\mathrm{pzc}}\right)$ of $\mathrm{Zn}-\mathrm{BTC}$.

As shown in Fig. 2, $\mathrm{pH}_{\mathrm{pzc}}$ of $\mathrm{Zn}-\mathrm{BTC}$ is 5.4, which mean
$\mathrm{pH}$ less than 5.4 resulting in negative charge at the surface of $\mathrm{Zn}$-BTC. And when pH of Zn-BTC is more than 5.4, the surface of $\mathrm{Zn}-\mathrm{BTC}$ is positive charged.

\section{B. Heavy Metal Removal}

Fig. 3 presents $\mathrm{Pb}(\mathrm{II})$ and $\mathrm{Cu}(\mathrm{II})$ removal efficiency of $\mathrm{Zn}-\mathrm{BTC}$ as a function of time. The results indicate that adsorption of $\mathrm{Pb}$ (II) and $\mathrm{Cu}$ (II) by $\mathrm{Zn}$-BTC reached equilibrium within 60 min contact time. Removal efficiencies at equilibrium were $90 \%$ and $70 \%$ for $\mathrm{Pb}(\mathrm{II})$ and $\mathrm{Cu}(\mathrm{II})$, respectively.

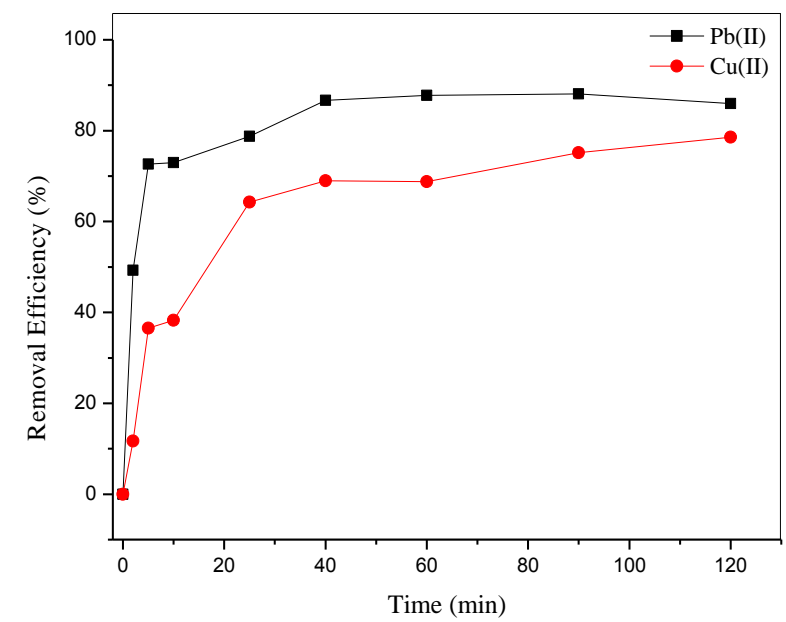

Fig. 3. Heavy metals removal by adsorption onto Zn-BTC $(\mathrm{Zn}-\mathrm{BTC}=0.5 \mathrm{~g} / \mathrm{L}$ $\left(\mathrm{C}_{0}=20 \mathrm{mg} / \mathrm{L}\right.$ for both $\mathrm{Pb}(\mathrm{II})$ and $\left.\mathrm{Cu}(\mathrm{II})\right)$.

\section{Adsorption Kinetics}

Table I presents pseudo-first order and pseudo-second order fitting with the experiment data. The greater $R^{2}$ value in the case of pseudo-second order suggests that the adsorption mechanism follow pseudo-second order in nature. The $R^{2}$ of fitting experimental data to the pseudo-second order were 0.999 for $\mathrm{Pb}(\mathrm{II})$ and 0.997 for $\mathrm{Cu}(\mathrm{II})$.

TABLE I: KINETIC OF THE ADSORPTION OF PB(II) AND CU(II) BY ZN-BTC

\begin{tabular}{lcc}
\hline & $\mathrm{Pb}(\mathrm{II})$ & $\mathrm{Cu}(\mathrm{II})$ \\
\hline Pseudo-first order & & \\
$k_{1}(1 / \mathrm{min})$ & -0.025 & -0.030 \\
$q_{e}(\mathrm{mg} / \mathrm{g})$ & 7.270 & 11.41 \\
$R^{2}$ & 0.883 & 0.739 \\
Pseudo-second order & & \\
$k_{2}$ & 0.011 & 0.003 \\
$q_{e}(\mathrm{mg} / \mathrm{g})$ & 39.37 & 36.10 \\
$R^{2}$ & 0.999 & 0.997 \\
\hline
\end{tabular}

The kinetic for adsorption process, fitting of kinetic models, show in Table I. The kinetic of heavy metal by Zn-BTC were analyzed by used of kinetic models, which were pseudo-first order and pseudo-second order. The experiment data calculate value was by $R^{2}$. The good of fit was evaluated by $R^{2}$ value that obtained for kinetic models. The pseudo-second order better fitting than the pseudo-first order because it has the higher $R^{2}$. The linear $\mathrm{Pb}$ (II) and $\mathrm{Cu}$ (II) obtained was $R^{2}=0.999$ and 0.997 , respectively.

\section{Adsorption Isotherm}

Table II presents Langmuir, Freundlich, and 
Dubinin-Radushkevitch isotherms fitting with the experiment adsorption data. Isotherm fitting was evaluated using $R^{2}$ value. Langmuir isotherm $\left(R^{2}=0.985\right.$ for $\mathrm{Pb}(\mathrm{II})$ and 0.997 for $\mathrm{Cu}(\mathrm{II}))$ provides better fitting than Freundlich isotherm $\left(R^{2}=0.866\right.$ for $\mathrm{Pb}(\mathrm{II})$ and 0.877 for $\left.\mathrm{Cu}(\mathrm{II})\right)$. Thus, suggests the monolayer adsorption of $\mathrm{Pb}$ (II) and $\mathrm{Cu}(\mathrm{II})$ by $\mathrm{Zn}$-BTC. The maximum adsorption capacity of $\mathrm{Pb}$ (II) was $417 \mathrm{mg}$ and $\mathrm{Cu}(\mathrm{II})$ was $85.5 \mathrm{mg}$ per $\mathrm{g}$ of $\mathrm{Zn}-\mathrm{BTC}$.

TABLE II: ADSORPTION DATA TO ISOTHERM MODELS FOR THE REMOVAL OF HEAVY METAL BY ZN-BTC

\begin{tabular}{lcc}
\hline & $\mathrm{Pb}(\mathrm{II})$ & $\mathrm{Cu}(\mathrm{II})$ \\
\hline Langmuir & & \\
$R^{2}$ & 0.985 & 0.997 \\
$q_{\max }(\mathrm{mg} / \mathrm{g})$ & 417.0 & 85.5 \\
$K_{L}$ & 0.021 & 0.104 \\
& & \\
Freundlich & & \\
$R^{2}$ & 0.866 & 0.877 \\
$n$ & 1.88 & 3.51 \\
$K_{f}(\mathrm{mg} / \mathrm{g})$ & 19.08 & 19.07 \\
& & \\
Dubinin-Radushkevich & & \\
$R^{2}$ & 0.846 & 0.999 \\
$\square$ & $6.00 \times 10^{-6}$ & $4.00 \times 10^{-6}$ \\
$E(\mathrm{~kJ} / \mathrm{mol})$ & 0.289 & 0.354 \\
\hline
\end{tabular}

The values of the free energy $(E)$ was calculated with Dubinin-Radushkevitch isotherm. Adsorption of $\mathrm{Pb}(\mathrm{II})$ and $\mathrm{Cu}$ (II) onto Zn-BTC resulted in $E=0.289$ and $0.354 \mathrm{~kJ} / \mathrm{mol}$, respectively. These free energy values were less than 8 $\mathrm{kJ} / \mathrm{mol}$, suggests that the absorption was the physical in nature.

\section{CONCLUSIONS}

In this study, Zn-BTC was successfully synthesized by hydrothermal method. Zn-BTC was able to remove $\mathrm{Pb}$ (II) and $\mathrm{Cu}(\mathrm{II})$ by adsorption mechanism and the removal efficiencies were $90 \%$ and $70 \%$, respectively. The point of zero charge $\left(\mathrm{pH}_{\mathrm{pzc}}\right)$ of $\mathrm{Zn}-\mathrm{BTC}$ was 5.4. Adsorption mechanisms followed pseudo-second order $\left(R^{2}=0.999\right.$ for $\mathrm{Pb}$ and $R^{2}=0.997$ for $\left.\mathrm{Cu}(\mathrm{II})\right)$. The adsorption isotherm also fitted well with Langmuir model $\left(R^{2}=0.985\right.$ for $\mathrm{Pb}$ (II) and 0.997 for $\mathrm{Cu}(\mathrm{II})$ ). The maximum adsorption capacity of $\mathrm{Pb}(\mathrm{II})$ was 417 $\mathrm{mg}$ and $\mathrm{Cu}(\mathrm{II})$ was $85.5 \mathrm{mg}$ per $\mathrm{g}$ of $\mathrm{Zn}$-BTC. The free energy (E) suggests that the absorption was the physical in nature. In the future, would to increase efficiency and develop adsorbent for heavy metal removal.

\section{ACKNOWLEDGMENT}

This work was financially supported by Research Center for Environmental and Hazardous Substance Management (EHSM), Khon Kaen University.

\section{REFERENCES}

[1] P. C. Department, "Notification the Ministry of Science, Technology and Environment, no. 3, B.E. 2539 (1996) issued under the Enhancement and Conservation of the National Environmental Quality Act B.E.2535 (1992)," The Royal Government Gazette, vol. 113, part 13 D, pp. 85-89, 1996.

[2] WHO, Guidelines for Drinking-water Quality, vol. 1, 2011.

[3] C. J. Madadrang et al., "Adsorption behavior of EDTA-graphene oxide for $\mathrm{Pb}$ (II) removal," ACS Applied Materials and Interfaces, vol. 4, no. 3, pp. 1186-1193, 2012.
[4] X. Huang and M. Pan, "The highly efficient adsorption of $\mathrm{Pb}$ (II) on graphene oxides: A process combined by batch experiments and modeling techniques," Journal of Molecular Liquids, 2016.

[5] Y. Zhang et al., "Adsorption of $\mathrm{Pb}$ (II) and $\mathrm{Hg}$ (II) from aqueous solution using magnetic $\mathrm{CoFe}_{2} \mathrm{O}_{4}$-reduced graphene oxide," Journal of Molecular Liquids, 2014.

[6] M. Yari et al., "Kinetics of the adsorption of $\mathrm{Pb}$ (II) ions from aqueous solutions by graphene oxide and thiol functionalized graphene oxide," Journal of Molecular Liquids, 2015.

[7] P. Duan, C. Yan, W. Zhou, and D. Ren, "Development of fly ash and iron ore tailing based porous geopolymer for removal of $\mathrm{Cu}$ (II) from wastewater," Ceramics International, vol. 42, no. 12, pp. 13507-13518, 2016.

[8] J. Yu et al., "The synthesis and application of zeolitic material from fly ash by one-pot method at low temperature," Green Energy \& Environment, pp. 4-9, 2016.

[9] J. Luo, H. Zhang, and J. Yang, "Hydrothermal Synthesis of Sodalite on Alkali-Activated Coal Fly Ash for Removal of Lead Ions," Procedia Environmental Sciences, vol. 31, pp. 605-614, 2016.

[10] N. A. Khan, Z. Hasan, and S. H. Jhung, "Adsorptive removal of hazardous materials using metal-organic frameworks (MOFs): A review," Journal of Hazardous Materials, vol. 244-245, pp. 444-456, 2013.

[11] S. L. James, Metal-organic Frameworks, 2003.

[12] A. Putkham, Application of Metal-Organic Frameworks for Carbon Dioxide Capture, vol. 18, no. 1, pp. 161-177, 2013.

[13] C. T. Pereira da Silva et al., "Synthesis of Zn-BTC metal organic framework assisted by a home microwave oven and their unusual morphologies," Materials Letters, vol. 182, pp. 231-234, 2016.

[14] F. Israr, D. K. Kim, Y. Kim, S. J. Oh, K. C. Ng, and W. Chun, "Synthesis of porous $\mathrm{Cu}-\mathrm{BTC}$ with ultrasonic treatment: Effects of ultrasonic power and solvent condition," Ultrasonics Sonochemistry, vol. 29, pp. 186-193, 2016.

[15] T. B. Čelič, M. Mazaj, N. Guillou, V. Kaučič, and N. Z. Logar, "New zinc-based metal organic framework material," in Proc. 3rd Croatian-Slovenian Symposium on Zeolites, pp. 43-46.

[16] N. Bakhtiari and S. Azizian, "Adsorption of copper ion from aqueous solution by nanoporous MOF-5: A kinetic and equilibrium study," Journal of Molecular Liquids, vol. 206, pp. 114-118, 2015.

[17] C. Chiericatti, J. C. Basilico, M. L. Zapata Basilico, and J. M. Zamaro, "Novel application of HKUST-1 metal-organic framework as antifungal: Biological tests and physicochemical characterizations," Microporous and Mesoporous Materials, 2012.

[18] Z. Q. Li, J. C. Yang, K. W. Sui, and N. Yin, "Facile synthesis of metal-organic framework MOF-808 for arsenic removal," Materials Letters, vol. 160, pp. 412-414, 2015.

[19] Y. Wang, G. Ye, H. Chen, X. Hu, Z. Niu, and S. Ma, "Functionalized metal-organic framework as a new platform for efficient and selective removal of cadmium(II) from aqueous solution," Journal of Materials Chemistry A, vol. 3, no. 29, pp. 15292-15298, 2015.

[20] L. Cui et al., "EDTA functionalized magnetic graphene oxide for removal of $\mathrm{Pb}(\mathrm{II}), \mathrm{Hg}$ (II) and $\mathrm{Cu}$ (II) in water treatment: Adsorption mechanism and separation property," Chemical Engineering Journal, 2015.

[21] T. Jiang et al., "Adsorption behavior of copper ions from aqueous solution onto graphene oxide-CdS composite," Chemical Engineering Journal, vol. 259, pp. 603-610, 2015.

[22] N. Bakhtiari, S. Azizian, S. M. Alshehri, N. L. Torad, V. Malgras, and Y. Yamauchi, "Study on adsorption of copper ion from aqueous solution by MOF-derived nanoporous carbon," Microporous and Mesoporous Materials, vol. 217, pp. 173-177, 2015.

[23] R. M. Ali, H. A. Hamad, M. M. Hussein, and G. F. Malash, "Potential of using green adsorbent of heavy metal removal from aqueous solutions: Adsorption kinetics, isotherm, thermodynamic, mechanism and economic analysis," Ecological Engineering, vol. 91, pp. 317-332, 2016.

[24] J. Cruz-Olivares, C. Pérez-Alonso, C. Barrera-Díaz, R. Natividad, and M. C. Chaparro-Mercado, "Thermodynamical and analytical evidence of lead ions chemisorption onto Pimenta dioica," Chemical Engineering Journal, vol. 166, no. 3, pp. 814-821, 2011.

[25] S. S.E. and T. N., "Isotherm, kinetic and thermodynamic studies on the adsorption behavior of textile dyes onto chitosan," Process Safety and Environmental Protection, vol. 106, pp. 1-10, 2016.

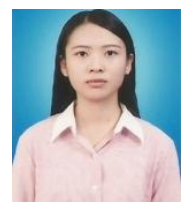

Chanutyaporn Kowsura is master degree student in Department of Environmental Engineering, Faculty of Engineering, Khon Kaen University, Thailand. Ms. Chanutyaporn Kowsura is interested in Metal-organic frameworks, Nano-materials, and Wastewater treatment. 
Bhuckchanya Pangkumhang is a doctoral degree studen in the Department of Environmental Engineering, Faculty of Engineering, Khon Kaen University, Thailand. Ms. Bhuckchanya Pangkumhang is interested in metal-organic frameworks, nano-materials, wastewater treatment, and application of materials.

Panitan Jutaporn is a lecturer at the Department of Environmental Engineering, Faculty of Engineering, Khon Kaen University, Thailand. Mrs. Panitan Jutaporn is interested in membrane technology, waste water treatment, ion exchange resin and energy.

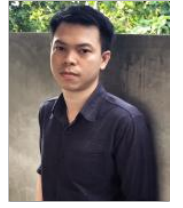

Visanu Tanboonchuy is a lecturer at the Department of Environmental Engineering, Faculty of Engineering, Khon Kaen University, Thailand. Mr. Visanu Tanboonchuy is interested in nano-material synthesis, groundwater treatment, waste water treatment, adsorption, kinetic model and energy. 